OPEN ACCESS

Edited by:

Eric Reiter,

Institut National de la Recherche

Agronomique (INRA), France

Reviewed by:

Seungkirl Ahn,

Duke University Medical Center,

United States

Guillermo Romero,

University of Pittsburgh, United States

${ }^{*}$ Correspondence:

László Hunyady

hunyady.laszlo@

med.semmelweis-univ.hu

Specialty section

This article was submitted to

Cellular Endocrinology,

a section of the journal

Frontiers in Endocrinology

Received: 26 April 2019

Accepted: 15 July 2019

Published: 06 August 2019

Citation:

Turu G, Balla A and Hunyady L (2019)

The Role of $\beta$-Arrestin Proteins in

Organization of Signaling and

Regulation of the AT1 Angiotensin

Receptor. Front. Endocrinol. 10:519.

doi: 10.3389/fendo.2019.00519

\section{The Role of $\beta$-Arrestin Proteins in Organization of Signaling and Regulation of the AT1 Angiotensin Receptor}

\author{
Gábor Turu ${ }^{1,2}$, András Balla ${ }^{1,2}$ and László Hunyady ${ }^{1,2 *}$ \\ ${ }^{1}$ Department of Physiology, Faculty of Medicine, Semmelweis University, Budapest, Hungary, ${ }^{2}$ MTA-SE Laboratory of \\ Molecular Physiology, Semmelweis University, Hungarian Academy of Sciences, Budapest, Hungary
}

AT1 angiotensin receptor plays important physiological and pathophysiological roles in the cardiovascular system. Renin-angiotensin system represents a target system for drugs acting at different levels. The main effects of ATR1 stimulation involve activation of Gq proteins and subsequent IP3, DAG, and calcium signaling. It has become evident in recent years that besides the well-known $G$ protein pathways, AT1R also activates a parallel signaling pathway through $\beta$-arrestins. $\beta$-arrestins were originally described as proteins that desensitize $G$ protein-coupled receptors, but they can also mediate receptor internalization and $G$ protein-independent signaling. AT1R is one of the most studied receptors, which was used to unravel the newly recognized $\beta$-arrestin-mediated pathways. $\beta$-arrestin-mediated signaling has become one of the most studied topics in recent years in molecular pharmacology and the modulation of these pathways of the AT1R might offer new therapeutic opportunities in the near future. In this paper, we review the recent advances in the field of $\beta$-arrestin signaling of the AT1R, emphasizing its role in cardiovascular regulation and heart failure.

Keywords: AT1 receptor, angiotensin II, signaling, biased agonism, arrestin

\section{INTRODUCTION}

AT1 angiotensin II receptor (AT1R) belongs to the G protein-coupled receptor (GPCR) family of membrane receptors and is activated by the octapeptide hormone, angiotensin II (AngII). AngII is the main effector of the renin-angiotensin system (RAS), which has pleiotropic effects in the cardiovascular system and salt-water balance regulation. As such, the RAS is an important target in the treatment of various cardiovascular diseases. AT1R blockers (ARBs) and angiotensin-converting enzyme inhibitors are widely used for the treatment of hypertension. Moreover, ARBs have beneficial effects beyond lowering the blood pressure, by preventing cardiovascular organ injuries (1). AngII can bind and activate two types of angiotensin receptors (type 1 and type 2 angiotensin receptors). Some cells contain AT2-receptors that mostly act via Gi and tyrosine phosphatases showing somewhat opposite effects to the AT1R-mediated cellular responses (2). However, the main physiological and pathological effects of RAS are mediated by AT1R. Initially, G protein activation was considered to be the only signal transduction process, which mediates the effects of AngII via AT1R. After AngII binding to AT1R, a heterotrimeric G protein, Gq mediates the hydrolysis of PtdIns(4,5)P2 by phosphoinositide-specific phospholipase $C \beta$ resulting in a generation of second messengers. In addition, AT1R can also couple to Gi/o and G12/13 
proteins leading to inhibition of adenylyl cyclase, activation of phospholipase D, Rho-kinase, and regulation of $\mathrm{Ca}^{2+}$ channels $(3,4)$.

Following their activation, GPCRs usually undergo G protein kinase (GRK) dependent phosphorylation on serine and threonine residues on their C-terminal tails. This phosphorylation leads to binding of $\beta$-arrestin proteins, which shut down $G$ protein activation and target the receptors toward internalization. During the last two decades it became increasingly evident that, in addition to $G$ proteins, $\beta$-arrestins can also mediate signaling events. $\beta$-arrestin proteins serve as scaffold proteins, bringing together the players of different protein kinase cascades, and instead of turning it off, they switch the signaling toward different routes (5). Like many other GPCRs, AT1R also binds $\beta$-arrestins, and $\beta$-arrestins regulate their internalization (6-8) Since the recognition of the role of $\beta$-arrestins in AT1R internalization, AT1R served as one of the most studied model for $\beta$-arrestin-dependent signaling, which has led to a completely new field in molecular pharmacology with the potential of development of new drugs, which may exploit the possibilities in selective activation of GPCR-activated signaling pathways.

\section{STRUCTURAL REQUIREMENTS FOR INTERNALIZATION AND $\beta$-ARRESTIN BINDING TO THE AT1R}

The binding of agonists to $G$ protein-coupled receptors initiate the "classical," G protein-mediated pathway, which results in the production of second messenger molecules. Termination of signaling has a key role in the regulation of the kinetics of receptor function. Mechanisms regulating receptor function include several consecutive or parallel processes, such as desensitization, internalization into intracellular vesicles, and degradation of the receptors. Receptor internalization is regulated by phosphorylation by GPCR kinases, which promotes the $\beta$-arrestin binding leading to desensitization, internalization and altered signaling of GPCRs (9). The role of a serine-threonine rich domain in the C-terminus of AT1R for angiotensin receptor internalization was first described in the laboratory of Kevin J. Catt (10-12). It was initially discovered with mutational and truncation analysis of AT1R that Thr332-Lys333Met334-Ser335-Thr336-Leu337-Ser338 amino acids, particularly the Ser335-Thr336-Leu337 motif on the C-terminus of the receptor are required for receptor internalization (10). A large number of serine and threonine amino acids in this region suggested the possible involvement of phosphorylation in its regulation. Indeed, Thr332, Ser335, Thr336, and Ser338 amino acids have been later identified as phosphorylation sites that regulate endocytosis (12-14), and involvement of $\beta$-arrestins in receptor internalization was verified $(6,15)$. The same serine and threonine amino acids were identified as the region critical for stable interaction between AT1R and $\beta$-arrestins following AngII stimulation $(15,16)$. On $\beta$-arrestin, two critical lysins (K11 and $\mathrm{K} 12$ in $\beta$-arrestin2), the phosphate-binding residues, are responsible for the stable interaction (17-22). It turns out, that the interaction between the serine/threonine-rich region and these two lysins (the "stability lock") is responsible for the conformational rearrangement in $\beta$ arrestin2 protein, leading to recruitment of the members $(23,24)$ and activation of Erk MAPK cascade (16). Interestingly, not only receptor activation, but also PKC mediated phosphorylation of the inactive, unliganded AT1R alone leads to recruitment of $\beta$-arrestin2, receptor internalization and scaffolding of the signaling complex (24).

\section{THE CONCEPT OF BIASED AGONISM}

Ligand binding to a plasma membrane receptor can initiate several parallel signal transduction pathways leading to various responses in the cell. Ligands of the plasma membrane receptors were originally classified as agonists and antagonists (or more recently inverse agonists). However, several ligands are capable of selectively initiating one or more of distinct signal transduction pathways coupled to one receptor, which phenomenon has been referred to as "biased agonism" or "functional selectivity." It has been revealed that the biased agonism is an important feature of several members of the GPCR superfamily, and it is proposed that the biased agonists can serve as new therapeutic agents (25). Some of the GPCR ligands can selectively couple the given receptor to the different downstream signaling events, including $\mathrm{G}$ protein activation and $\beta$-arrestin-mediated signaling, leading to altered signaling patterns compared to the natural agonist. The background of this phenomenon is that the variant ligands cause distinct conformational changes in the structure of the receptor. The different conformations can lead to dissimilar interaction capabilities with $G$ proteins and to other partners. Another layer of complexity is introduced by the recognition of different phosphorylation patterns on the receptor C-terminus. It has been recognized, that different receptors bind arrestins with different affinities, some of which form stable (called class $B$ receptors) whereas others form loose interactions with $\beta$ arrestins (called class A receptors) (26). Interaction stability and arrestin activation seem to be determined by specific patterns of phosphorylated serine/threonine amino acids (22, 27). Moreover, different kinases may phosphorylate different residues on the $\mathrm{C}$-terminus, resulting in slightly different outcomes regarding internalization, signaling and activated $\beta$ arrestin conformations. This phenomenon has led to the barcode theory. Slightly different active receptor conformations, different cellular expression contexts, or even simultaneous stimulation of other receptors can lead to altered phosphorylation patterns, leading to different conformations of $\beta$-arrestins, and altered signaling (28-34). AT1R phosphorylation by GRK2/3 regulates receptor endocytosis, while phosphorylation by GRK5/6 activates Erk1/2 (35). Even PKC phosphorylation can initiate $\beta$-arrestin binding and recruitment of the MAPK machinery to the AT1R, although the binding affinity is lower and the active conformation of the $\beta$-arrestin is altered (24). These data together suggest, that signaling bias is not restricted to the G-protein- $\beta$-arrestin axis, but even $\beta$-arrestin dependent signaling may be finely tuned toward distinct outcomes depending on the actual stimulation and cellular context. 
Early studies had identified mutant receptors of the highly conserved Asp125Arg126Tyr127 sequence of AT1R (i.e., DRY/AAY mutation), which are not able to couple to $G$ proteins, but still capable to internalize and bind $\beta$-arrestins $(7,36)$. Using this mutant AT1R, it has been demonstrated that AT1R can cause ERK 1/2 phosphorylation or Src activation in the absence of $\mathrm{G}$ protein activation $(7,37,38)$. Furthermore, a biased AT1R agonist, [Sar1,Ile4,Ile8]-AngII (SII-AngII) was developed, which is a mutated octapeptide angiotensin analog unable to activate Gq-proteins, but still recruits $\beta$-arrestins to the AT1R and is able to evoke the internalization of the receptor (39). Thus, it acts as a biased agonist, which selectively activates $\beta$-arrestins. This octapeptide further widened the possibilities to investigate $G$ protein-independent mechanisms. It has been shown, that this agonist can also stimulate $G$ protein-independent mechanisms (7). It was proposed that $G$ protein-mediated MAP kinase activation regulates nuclear targets, while the $\beta$-arrestinmediated MAP kinases activation affects the phosphorylation of cytoplasmic proteins $(40,41)$. Also, compared to G-proteindependent Erk1/2 activation, $\beta$-arrestin-dependent Erk1/2 signaling is slower, reaching its maximum after $10 \mathrm{~min}$ and remains active for a prolonged time (40). Later, several new AngII peptide analogs have been developed and characterized with a bias toward $G$ protein or $\beta$-arrestin signaling (42-44). The discovery of the biased signaling has led to the recognition that AT1R may develop multiple active conformations, and this has been demonstrated by molecular dynamics simulations $(45,46)$ and experimentally (47-49). Conformational changes within AT1R may be followed with BRET sensors utilizing a small molecule acceptor (FlAsH molecule). When placed on different places within AT1R, different conformational changes following stimulation with distinct ligands can capture multiple activation states of the receptor (47). Different conformational states after binding of the different ligands have been further demonstrated using single molecular spectroscopy (48) and more recently using double electron-electron resonance spectroscopy in AT1R (49). The developed biased agonists serve now as widely used tools to study the biased agonism of the AT1R, and numerous of their effects on cell responses were published in recent years (50).

\section{SIGNALING PATHWAYS REGULATED BY AT1R THROUGH $\beta$-ARRESTIN}

$\beta$-arrestin-mediated mechanisms can be considered as the second wave of signal transduction events resulting in alternative outcomes. Moreover, the agonist binding of AT1R can lead to direct association with wide spectra of cytoplasmic signaling proteins, such as AT1R-associated protein (ATRAP), SHP-2, JAK2, $\beta$-arrestins, and phospholipase $C \gamma$, which explains a plethora of AT1R generated signaling mechanisms, including JAK/STAT pathway and MAPK cascade activation (51-54). The attached proteins can initiate diverse cellular responses from the receptor-arrestin complex and can form multiprotein units, "signalosomes" (55).

One such selectively activated pathway of particular interest is the $\beta$-arrestin-dependent signaling. $\beta$-arrestin-mediated signaling events include activation of Src tyrosine kinases extracellular signal-regulated kinase 1/2 (ERK 1/2), c-Jun $\mathrm{N}$-terminal kinase (JNK), mitogen-activated protein kinase (MAPK) cascades, Akt and p38 mitogen-activated protein kinases (56-59).

Besides the observation of Erk1/2 activation through $\beta$ arrestins, many other cellular functions have been discovered to be regulated through GPCRs in a non-canonical G proteinindependent way. These pathways include JNK3, p38, and Akt protein kinase regulation (56), some of which have been also implicated in AT1R signaling $(60,61)$. The pathways may include very broad signaling routes, including the increased protein synthesis via $\beta$-arrestin-mediated Mnk1, eIF4E, and ERK1/2 activation (62). The arrestin-biased ligand, SII-AngII is also able to increase the aldosterone synthesis in adrenocortical zona glomerulosa cells via $\beta$-arrestin, in addition to the AngII-induced Gq protein-dependent aldosterone production, which can lead to adverse cardiac remodeling and heart failure progression (63). Several proteomic and genetic studies were carried out to investigate the short and long term effects of the treatment of SII-AngII using both AT1R overexpressing cells and primary cell cultures. It has been demonstrated that the SII-AngII could initiate a robust $G$ protein-independent signaling network, and signaling pathways significantly differ than the AngII induced cellular responses. Kendall et al. demonstrated that the SIIAngII treatment changed the phosphorylation state of numerous downstream proteins, such as protein phosphatase $2 \mathrm{~A}$ and prostaglandin E synthase 3 (64). The inhibitory phosphorylation of protein phosphatase $2 \mathrm{~A}$ results in Akt activation and phosphorylation of glycogen synthase kinase $3 \beta$, whereas the prostaglandin $\mathrm{E}$ synthase 3 activation increases prostaglandin production both in AT1R expressing HEK293 cells and in rat aortic vascular smooth muscle cells (64). It is very astonishing that the SII-AngII-induced phosphorylation patterns have limited overlap with those of AngII-induced phosphorylation (64), suggesting that the $\beta$-arrestin activation initiates not only spatially, but also qualitatively different signaling events. Analyzing the $\beta$-arrestin-mediated phosphoproteome after SII stimulation of AT1R revealed a plethora of changes in protein phosphorylation, including a huge number of kinases and some phosphatases as well (65). Besides the activation of different kinase cascade signaling pathways, $\beta$-arrestindependent regulations of ion channels have been also reported following AT1R activation, including TRPV4 (66), TRPC3 (67), and CaV1.2 (68) channels.

\section{ROLE OF THE $\beta$-ARRESTIN DEPENDENT AT1R SIGNALING IN CARDIAC FUNCTION AND HEART FAILURE (HF)}

Since the AngII is a vasopressor hormone, its production and effects are very important in the development of numerous cardiovascular diseases such as hypertension, atherosclerosis, and cardiac hypertrophy. Indeed, AT1R blockers and inhibitors of AngII production (ACE inhibitors) are now extensively used in the treatment of hypertension and other cardiovascular diseases 
$(69,70)$. Special fields of interest, where RAS plays significant roles are cardiac hypertrophy and heart failure, where AngII seems to contribute to the pathophysiology of these conditions.

Both AT1R-activation of $G$ protein-dependent and $G$ protein-independent mechanisms contribute to the development of cardiac hypertrophy. It was demonstrated that heartspecific overexpression of different AT1R mutants can lead to hypertrophy, moreover, the mutant AT1R, which mediates only $G$ protein-independent signaling mechanisms, caused greater cardiac hypertrophy but less apoptosis and fibrosis than overexpression of wild-type AT1R (71). Contrary, in vascular smooth cells (VSMCs) only the G protein-dependent mechanism of AT1R, mediated by EGF receptor transactivation and Rho kinase activation, seems to be important in AngII-induced hypertrophy (72). However, $\beta$-arrestin 1 dependent activation of RhoA has been demonstrated as well, and interaction of AT1R with SHP2 through Y319 residue might be involved in EGF receptor transactivation $(73,74)$. Interestingly, with wild type AT1Rs, cardiac hypertrophy was reported to be dependent on G protein and metalloprotease activation but did not occur after $\beta$ arrestin biased SII-AngII stimulation of AT1Rs (75). According to Aplin et al., the G protein-independent signaling supports the non-hypertrophic proliferation of rat cardiomyocytes $(76,77)$.

In the development of pathological cardiac hypertrophy, mechanical stress is thought to be one of the most important factors. Parallel with the discoveries of the $\beta$-arrestin-dependent signaling through AT1R, AT1R receptor was also found to be involved in stretch-induced signaling pathways in various cell types. First, it has been discovered, that in cardiomyocytes, stretch-induced Erk1/2 activation was dependent on AT1Rs (7880 ). Since then, many further papers have been published with observations of mechanical stretch-induced, AT1R-mediated signaling in different cell types, including cardiomyocytes (81$85)$, vascular smooth muscle cells (86-89), renal podocytes (90), endothelial (91), and epidermal cells (92).

Interestingly, mechanical activation of AT1R caused increased affinity toward $\beta$-arrestin biased ligand TRV 120023 (93), suggesting stabilization of a biased active receptor conformation. Moreover, protein kinase $\mathrm{C}$ and GRK2, the kinase responsible for phosphorylation and subsequent $\beta$-arrestin binding of many GPCRs, has been reported to be activated upon stretch in neonatal rat ventricular myocytes (94). Indeed, hypo-osmotic stretch and mechanical stress induced $\beta$-arrestin translocation to the $\operatorname{AT} 1 \mathrm{R}(88,95)$. It turns out that EKR1/2 activation by mechanical stress through AT1R is $\beta$-arrestin dependent (95). Stretch-induced $\beta$-arrestin-dependent signaling may involve Erk1/2, Akt kinases, EGFR transactivation $(92,95)$, and Src may also play an important role in this process (96). In line with the very recent developments (see below), mechanically activated $\beta$ arrestin signaling may also involve the activation of $\mathrm{Gi} / \mathrm{o}$ proteins through AT1R (97).

The involvement of AT1R- $\beta$-arrestin interplay in cardiac function has become more evident with the discovery of the beneficial effects of biased AT1R ligands on the heart contractility. RAS is typically activated in patients with HF, with increased circulating AngII levels. Anti-RAS drugs, like AT1R blockers and ACE inhibitors, have been long proven beneficial in the treatment of HF. It seems that the pathological actions of AT1R on vasoconstriction and heart remodeling are mediated through Gq-protein activation. On the contrary, studies have suggested that TRV120023 and TRV120027, a $\beta$-arrestin biased ligand of AT1R, decrease blood pressure similarly to AT1R blockers, but unlike those drugs, it improves cardiac performance, preserves cardiac stroke volume, decreases systemic vascular resistance, improves cardiac output while preserving renal functions in animal models $(44,98)$.

Moreover, TRV120027, in combination with furosemide, decreased preload and afterload in dog models of HF, while furosemide-induced natriuresis and diuresis were preserved (98). Infusion of biased AT1R ligand TRV120023 into mice with familial dilated cardiomyopathy increased myosin lightchain phosphorylation and improved cardiac contractility (99). Earlier studies have already shown, that SII-AngII treatment can lead to increased cardiomyocyte inotropy and lusitropy (100), and in line with that, Frank-Starling mechanism of the heart, which describes the volume load-contractility relationship of the heart, has been found to be dependent both on AT1R and $\beta$ arrestins (101). Besides $\mathrm{Ca}^{2+}$ sensitization, in immature mouse cardiomyocytes, TRV120027 activates $\mathrm{CaV} 1.2 \mathrm{Ca}^{2+}$ channels as well through Src-family tyrosine kinases and casein kinase 2 in a $\beta$-arrestin-dependent manner (102).

After the initial promising results with biased AT1R ligands on the heart function, the first human study was reported in 2013 (103) and in the same year, the phase IIb study was initiated in patients with acute HF, and the results were reported in 2017 (104). Unfortunately, the results of this study did not confirm the beneficial effects of the biased AT1R activation, in fact, in none of the primary endpoints was observed an improved outcome. However, in this study, short time therapy was assessed; the patients were treated for only $48-96 \mathrm{~h}$ after within $24 \mathrm{~h}$ of initial presentation, and then the outcomes of acute heart failure were investigated. TRV120027 itself is an octapeptide, which has a half-life of only about a few minutes, so it has to be administered intravenously, and this restricts its long-time usability in patients. Therefore, although this study failed to justify the use of biased AT1R ligands in HF failure therapy, long-term treatment may be still beneficial. Indeed, a recent study on dilated cardiomyopathy mouse model showed improved cardiac structure and function after 3 months of TRV120067, another biased AT1R ligand treatment (105). However, TRV120067 is also a peptide, which limits its application in human patients in long-term therapy plans. The use of small molecules having $\beta$-arrestin biased activity on AT1R might be beneficial, however, to date, only one such molecule has been reported. Although troglitazone is a small molecule, potentially suitable for long-term treatments, this molecule has a very weak affinity toward AT1R, making it unattractive in in vivo experiments (106).

Although these experiments have very promising results, some important aspects of the RAS are often overlooked which may influence the in vivo results. It is widely accepted now, that AT1R can form heterodimers with other GPCRs, and the function of the heterodimers might be influenced by the active state of the AT1R. A classic example of interaction is bradykinin 
B2 receptor, but there are also other examples of interactions (38, 107-117). In HEK293 cells, SII-AngII inhibits B2 receptormediated Gq/11-dependent intracellular calcium influx when AT1R is coexpressed, showing that AT1R-biased ligands effects might be mediated not only by $\beta$-arrestins, but also by more complex interactions between different GPCRs (118). Another often overlooked aspect of the biased ligand actions is the presence of the other angiotensin II receptor in vivo, the AT2 angiotensin receptor (AT2R). Although the AT2R does not bind $\beta$-arrestins upon Ang II stimulation (119), it still may play role in in vivo effects of the AT1R biased agonists. SII-AngII, TRV120023 and TRV120027 seem to bind to this receptor as well, but their effects were mediated through AT1R in experiments where AT2 receptors were checked $(44,120,121)$. However, to our knowledge, the effects of these ligands have not been thoroughly tested on AT2R.

In any case, with the better understanding of the AT1R conformation upon biased activation (45-49), and the readily availability of bioinformatical tools in drug screening (122), the discovery of high affinity drugs with small molecular weight might not be that far.

\section{IS $\beta$-ARRESTIN SIGNALING G PROTEIN-INDEPENDENT?}

Originally, $\beta$-arrestin-mediated signaling was thought to be independent of $G$ protein activation. In fact, AT1R-activated pathways have been usually divided into $G$ protein-dependent and $G$ protein-independent (e.g., $\beta$-arrestin-dependent), since AT1R mutants used in the studies and biased AT1R ligands failed to activate the usual Gq-protein signaling with IP3 and DAG production and consequent $\mathrm{Ca}^{2+}$ signal generation. It has challenged the concept of the clean $\beta$-arrestin dependent Erk1/2 activation when SII-AngII, the most widely used $\beta$ arrestin biased ligand, has been shown to activate $\mathrm{Gq}$ and
Gi proteins, however with much weaker efficacy then AngII (123). In addition, this Erk1/2 activation was dependent on $\mathrm{G}$ protein activation. Similarly, the mechanic stretch-induced activation of Erk1/2 signaling seems to be also Gi-dependent, although in this setup, $\beta$-arrestin biased ligands (TRV12023 and TRV12026) did not require Gi coupling (97). However, very recently, using pathway-wide BRET signaling sensors, 14 different AT1R ligands have been tested, including the $\beta$-arrestin biased ones, such as TRV120027. Strikingly, all of the tested ligands activated Gi and G12 proteins with some efficacy (124), raising the possibility that some $\beta$-arrestin-dependent signaling pathways may utilize one or more $G$ protein-dependent signaling mechanisms. Indeed, another recent study has used CRISPRCas9 system to switch off all G proteins, including G12/13 and used PTX to inhibit Gi (“zero functional G” setup) (125). They found, that although $\beta$-arrestin still couples to a set of GPCRs, with no functional $G$ proteins, the Erk1/2 could not be activated. On the other hand, CRISPR deletion of $\beta$-arrestin $1 / 2$ results in various effects on Erk1/2 signaling, depending on the cell line and receptor type, it may be enhanced, inhibited or unchanged (126). These data show that the picture of $\beta$-arrestin-mediated signaling is more complex than we originally thought. The cellular background, adaptive mechanisms, $\beta$-arrestin's dual role (desensitization and activation of $\beta$-arrestin-dependent Erk1/2 signaling) lead to a very complex regulation mechanism where the end-effect on the signaling cascade will be determined on the interplay of these aspects (126). The available data suggest that during $\beta$-arrestin-signaling a complex interplay occurs between $\beta$-arrestin-signaling and kinase cascades. This model could explain the recent developments of the field. Although $\beta$-arrestin sequestrates together with all the components of the cRaf/MEK/Erk1/2 cascade, the activation of the most proximal kinase in the cascade may be kicked on by $\beta$-arrestin-independent mechanisms, which might be either a $G$ proteins, or in more physiological settings, one of the classical, growth factor receptors $(56,127)$. So far, at least three different

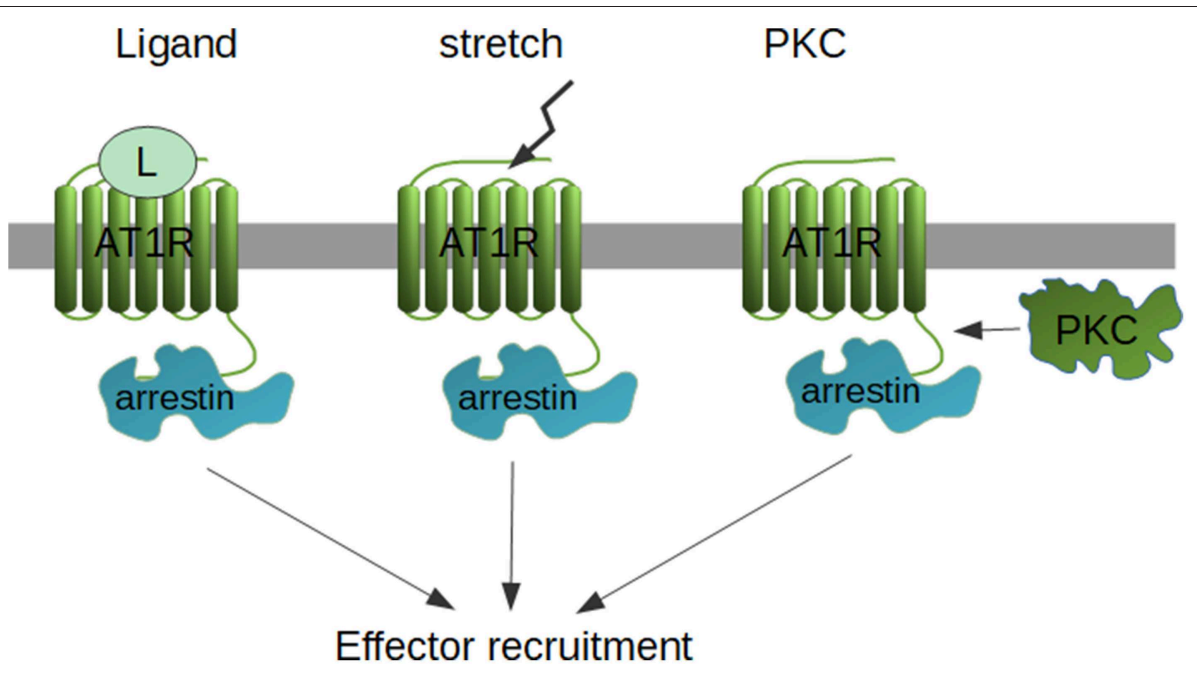

FIGURE 1 | Possibilities of $\beta$-arrestin recruitment. $\beta$-arrestins are recruited to the AT1R either by activation by ligand or stretch, or by PKC-dependent phosphorylation of the unliganded receptor. 
mechanisms may lead to $\beta$-arrestin coupling to the AT1R, the classical ligand-dependent way, mechanical stretch and PKC activation (Figure 1). When no other stimulus is present, $\beta$ arrestins might not be able to activate the most proximal kinases, but when they are already activated, it brings together all the pieces of the signaling cascade and orchestrates their spatiotemporal regulation.

\section{CONCLUDING REMARKS AND FUTURE PERSPECTIVES}

We have come a long way in the recent almost 20 years since the interaction of AT1R and $\beta$-arrestin has been discovered. The interaction of these two proteins itself had a huge effect in understanding how the GPCRs function, and how are the signaling pathways regulated beside the classical $G$ protein activation. We are at the doorstep of therapeutic

\section{REFERENCES}

1. Ishimitsu T, Honda T, Ohno E, Furukata S, Sudo Y, Nakano N, et al. Year-long antihypertensive therapy with candesartan completely prevents development of cardiovascular organ injuries in spontaneously hypertensive rats. Int Heart J. (2010) 51:359-64. doi: 10.1536/ihj.51.359

2. Porrello ER, Delbridge LMD, Thomas WG. The angiotensin II type 2 (AT2) receptor: an enigmatic seven transmembrane receptor. Front Biosci. (2009) 14:958-72. doi: 10.2741/3289

3. Hunyady L, Catt KJ. Pleiotropic AT1 receptor signaling pathways mediating physiological and pathogenic actions of angiotensin II. Mol Endocrinol. (2006) 20:953-70. doi: 10.1210/me.2004-0536

4. Kawai T, Forrester SJ, O'Brien S, Baggett A, Rizzo V, Eguchi S. AT1 receptor signaling pathways in the cardiovascular system. Pharmacol Res. (2017) 125:4-13. doi: 10.1016/j.phrs.2017.05.008

5. Shukla AK, Xiao K, Lefkowitz RJ. Emerging paradigms of $\beta$-arrestindependent seven transmembrane receptor signaling. Trends Biochem Sci. (2011) 36:457-69. doi: 10.1016/j.tibs.2011.06.003

6. Gáborik Z, Szaszák M, Szidonya L, Balla B, Paku S, Catt KJ, et al. $\beta$-arrestinand dynamin-dependent endocytosis of the AT1 angiotensin receptor. Mol Pharmacol. (2001) 59:239-47. doi: 10.1124/mol.59.2.239

7. Wei H, Ahn S, Shenoy SK, Karnik SS, Hunyady L, Luttrell LM, et al. Independent beta-arrestin 2 and G protein-mediated pathways for angiotensin II activation of extracellular signal-regulated kinases 1 and 2. Proc Natl Acad Sci USA. (2003) 100:10782-7. doi: 10.1073/pnas.18345 56100

8. Zhang J, Barak LS, Anborgh PH, Laporte SA, Caron MG, Ferguson SSG. Cellular trafficking of $G$ protein-coupled receptor/ $\beta$ arrestin endocytic complexes. J Biol Chem. (1999) 274:10999-1006. doi: 10.1074/jbc.274.16.10999

9. DeWire SM, Ahn S, Lefkowitz RJ, Shenoy SK. $\beta$-arrestins and cell signaling. Annu Rev Physiol. (2007) 69:483-510. doi: 10.1146/annurev.physiol.69.022405.154749

10. Hunyady L, Bor M, Balla T, Catt KJ. Identification of a cytoplasmic SerThr-Leu motif that determines agonist-induced internalization of the AT1 angiotensin receptor. J Biol Chem. (1994) 269:31378-82.

11. Hunyady L, Catt KJ, Clark AJL, Gáborik Z. Mechanisms and functions of AT(1) angiotensin receptor internalization. Regul Pept. (2000) 91:29-44. doi: 10.1016/S0167-0115(00)00137-3

12. Smith RD, Hunyady L, Olivares-Reyes JA, Mihalik B, Jayadev S, Catt KJ. Agonist-induced phosphorylation of the angiotensin ATla receptor is localized to a serine/threonine-rich region of its cytoplasmic tail. $\mathrm{Mol}$ Pharmacol. (1998) 54:935-41. doi: 10.1124/mol.54.6.935 exploitation of this system, and although the first attempt to cross it was not successful, recent results suggest that this was probably not our last chance. Recent advances in the field also show that there might be still a lot learn about $\beta$-arrestindependent signaling, and AT1R might further serve as a good model for such experiments.

\section{AUTHOR CONTRIBUTIONS}

All authors listed have made a substantial, direct and intellectual contribution to the work, and approved it for publication.

\section{FUNDING}

This work was supported by Hungarian National Research, Development and Innovation Fund Grants NVKP_16-1-20160039 and K116954.

13. Qian H, Pipolo L, Thomas WG. Identification of protein kinase C phosphorylation sites in the angiotensin II (AT1A) receptor. Biochem J. (1999) 343(Pt 3):637-44. doi: 10.1042/bj3430637

14. Thomas WG, Motel TJ, Kule CE, Karoor V, Baker KM. Phosphorylation of the angiotensin II (AT 1A) receptor carboxyl terminus: a role in receptor endocytosis. Mol Endocrinol. (1998) 12:1513-24. doi: $10.1210 /$ mend.12.10.0179

15. Qian H, Pipolo L, Thomas WG. Association of $\beta$-Arrestin 1 with the type $1 \mathrm{~A}$ angiotensin II receptor involves phosphorylation of the receptor carboxyl terminus and correlates with receptor internalization. Mol Endocrinol. (2001) 15:1706-19. doi: 10.1210/me.15.10.1706

16. Wei H, Ahn S, Barnes WG, Lefkowitz RJ. Stable interaction between $\beta$ arrestin 2 and angiotensin type $1 \mathrm{~A}$ receptor is required for $\beta$-arrestin 2 mediated activation of extracellular signal-regulated kinases 1 and 2. J Biol Chem. (2004) 279:48255-61. doi: 10.1074/jbc.M406205200

17. Gimenez LE, Kook S, Vishnivetskiy SA, Ahmed MR, Gurevich EV, Gurevich VV. Role of receptor-attached phosphates in binding of visual and non-visual arrestins to G protein-coupled receptors. J Biol Chem. (2012) 287:9028-40. doi: 10.1074/jbc.M111.311803

18. Gimenez LE, Babilon S, Wanka L, Beck-Sickinger AG, Gurevich VV. Mutations in arrestin-3 differentially affect binding to neuropeptide Y receptor subtypes. Cell Signal. (2014) 26:1523-31. doi: 10.1016/j.cellsig.2014.03.019

19. Gurevich VV, Gurevich EV. The structural basis of arrestin-mediated regulation of G-protein-coupled receptors. Pharmacol Ther. (2006) 110:465502. doi: 10.1016/j.pharmthera.2005.09.008

20. Shenoy SK, Lefkowitz RJ. Receptor-specific ubiquitination of $\beta$ arrestin directs assembly and targeting of seven-transmembrane receptor signalosomes. J Biol Chem. (2005) 280:15315-24. doi: 10.1074/jbc.M412418200

21. Shukla AK, Manglik A, Kruse AC, Xiao K, Reis RI, Tseng W-C, et al. Structure of active $\beta$-arrestin-1 bound to a G-protein-coupled receptor phosphopeptide. Nature. (2013) 497:137-41. doi: 10.1038/nature12120

22. Zhou XE, He Y, de Waal PW, Gao X, Kang Y, Van Eps N, et al. Identification of phosphorylation codes for arrestin recruitment by $g$ proteincoupled receptors. Cell. (2017) 170:457-469.e13. doi: 10.1016/j.cell.2017. 07.002

23. Gulyás G, Tóth JT, Tóth DJ, Kurucz I, Hunyady L, Balla T, et al. Measurement of inositol 1,4,5-trisphosphate in living cells using an improved set of resonance energy transfer-based biosensors. PLoS ONE. (2015) 10:e0125601. doi: 10.1371/journal.pone.0125601

24. Tóth AD, Prokop S, Gyombolai P, Várnai P, Balla A, Gurevich VV, et al. Heterologous phosphorylation-induced formation of a stability lock permits 
regulation of inactive receptors by $\beta$-arrestins. J Biol Chem. (2018) 293:87692. doi: 10.1074/jbc.M117.813139

25. Whalen EJ, Rajagopal S, Lefkowitz RJ. Therapeutic potential of $\beta$-arrestinand G protein-biased agonists. Trends Mol Med. (2011) 17:126-39. doi: 10.1016/j.molmed.2010.11.004

26. Oakley RH, Laporte SA, Holt JA, Caron MG, Barak LS. Differential affinities of visual arrestin, $\beta$ Arrestin1, and $\beta$ Arrestin2 for $G$ protein-coupled receptors delineate two major classes of receptors. J Biol Chem. (2000) 275:17201-10. doi: 10.1074/jbc.M910348199

27. Mayer D, Damberger FF, Samarasimhareddy M, Feldmueller M, Vuckovic $\mathrm{Z}$, Flock $\mathrm{T}$, et al. Distinct $\mathrm{G}$ protein-coupled receptor phosphorylation motifs modulate arrestin affinity and activation and global conformation. Nat Commun. (2019) 10:1261. doi: 10.1038/s41467-019-09204-y

28. Busillo JM, Armando S, Sengupta R, Meucci O, Bouvier M, Benovic JL. Site-specific phosphorylation of CXCR4 is dynamically regulated by multiple kinases and results in differential modulation of CXCR4 signaling. $J$ Biol Chem. (2010) 285:7805-17. doi: 10.1074/jbc.M109.091173

29. Butcher AJ, Prihandoko R, Kong KC, McWilliams P, Edwards JM, Bottrill A, et al. Differential G-protein-coupled receptor phosphorylation provides evidence for a signaling bar code. J Biol Chem. (2011) 286:11506-18. doi: 10.1074/jbc.M110.154526

30. Jean-Charles P-Y, Kaur S, Shenoy SK. G protein-coupled receptor signaling through $\beta$-arrestin-dependent mechanisms. J Cardiovasc Pharmacol. (2017) 70:142-58. doi: 10.1097/FJC.0000000000000482

31. Nobles KN, Xiao K, Ahn S, Shukla AK, Lam CM, Rajagopal S, et al. Distinct phosphorylation sites on the $\beta(2)$-adrenergic receptor establish a barcode that encodes differential functions of $\beta$-arrestin. Sci Signal. (2011) 4:ra51. doi: 10.1126/scisignal.2001707

32. Smith JS, Rajagopal S. The $\beta$-arrestins: multifunctional regulators of G protein-coupled receptors. I Biol Chem. (2016) 291:8969-77. doi: $10.1074 /$ jbc.R115.713313

33. Tobin AB, Butcher AJ, Kong KC. Location, location, location site-specific GPCR phosphorylation offers a mechanism for cell-type-specific signalling. Trends Pharmacol Sci. (2008) 29:413-20. doi: 10.1016/j.tips.2008.05.006

34. Yang F, Yu X, Liu C, Qu C, Gong Z, Liu H, et al. Phospho-selective mechanisms of arrestin conformations and functions revealed by unnatural amino acid incorporation and 19F-NMR. Nat Commun. (2015) 6:8202. doi: $10.1038 /$ ncomms 9202

35. Kim J, Ahn S, Ren X-R, Whalen EJ, Reiter E, Wei H, et al. Functional antagonism of different $\mathrm{G}$ protein-coupled receptor kinases for $\beta$-arrestinmediated angiotensin II receptor signaling. Proc Natl Acad Sci USA. (2005) 102:1442-7. doi: 10.1073/pnas.0409532102

36. Gáborik Z, Jagadeesh G, Zhang M, Spät A, Catt KJ, Hunyady L. The role of a conserved region of the second intracellular loop in AT1 angiotensin receptor activation and signaling. Endocrinology. (2003) 144:2220-8. doi: 10.1210/en.2002-0135

37. Hansen JL, Aplin M, Hansen JT, Christensen GL, Bonde MM, Schneider M, et al. The human angiotensin AT1 receptor supports G protein-independent extracellular signal-regulated kinase $1 / 2$ activation and cellular proliferation. Eur J Pharmacol. (2008) 590:255-63. doi: 10.1016/j.ejphar.2008.05.010

38. Karip E, Turu G, Süpeki K, Szidonya L, Hunyady L. Cross-inhibition of angiotensin AT1 receptors supports the concept of receptor oligomerization. Neurochem Int. (2007) 51:261-7. doi: 10.1016/j.neuint.2007.05.018

39. Holloway AC, Qian H, Pipolo L, Ziogas J, Miura S, Karnik S, et al. Side-chain substitutions within angiotensin II reveal different requirements for signaling, internalization, and phosphorylation of type $1 \mathrm{~A}$ angiotensin receptors. Mol Pharmacol. (2002) 61:768-77. doi: 10.1124/mol.61.4.768

40. Ahn S, Shenoy SK, Wei H, Lefkowitz RJ. Differential kinetic and spatial patterns of $\beta$-arrestin and G protein-mediated ERK activation by the angiotensin II receptor. J Biol Chem. (2004) 279:35518-25. doi: 10.1074/jbc.M405878200

41. Tohgo A, Pierce KL, Choy EW, Lefkowitz RJ, Luttrell LM. $\beta$-arrestin scaffolding of the ERK cascade enhances cytosolic ERK activity but inhibits ERK-mediated transcription following angiotensin ATla receptor stimulation. J Biol Chem. (2002) 277:9429-36. doi: 10.1074/jbc.M106457200

42. Rajagopal S, Ahn S, Rominger DH, Gowen-MacDonald W, Lam CM, Dewire $\mathrm{SM}$, et al. Quantifying ligand bias at seven-transmembrane receptors. Mol Pharmacol. (2011) 80:367-77. doi: 10.1124/mol.111.072801
43. Strachan RT, Sun J, Rominger DH, Violin JD, Ahn S, Rojas Bie Thomsen $A$, et al. Divergent transducer-specific molecular efficacies generate biased agonism at a G protein-coupled receptor (GPCR). J Biol Chem. (2014) 289:14211-24. doi: 10.1074/jbc.M114.548131

44. Violin JD, DeWire SM, Yamashita D, Rominger DH, Nguyen L, Schiller K, et al. Selectively engaging $\beta$-arrestins at the angiotensin II type 1 receptor reduces blood pressure and increases cardiac performance. J Pharmacol Exp Ther. (2010) 335:572-9. doi: 10.1124/jpet.110.173005

45. Cabana J, Holleran B, Leduc R, Escher E, Guillemette G, Lavigne P. Identification of distinct conformations of the angiotensin-II type 1 receptor associated with the $\mathrm{G}_{\mathrm{q} / 11}$ protein pathway and the $\beta$-arrestin pathway using molecular dynamics simulations. J Biol Chem. (2015) 290:15835-54. doi: 10.1074/jbc.M114.627356

46. Modestia SM, Malta de Sá M, Auger E, Trossini GHG, Krieger JE, Rangel-Yagui CO. Biased agonist TRV027 determinants in AT1R by molecular dynamics simulations. J Chem Inf Model. (2019) 59:797-808. doi: $10.1021 /$ acs.jcim. 8 b00628

47. Devost D, Sleno R, Pétrin D, Zhang A, Shinjo Y, Okde R, et al. Conformational profiling of the AT1 angiotensin II receptor reflects biased agonism, G protein coupling, and cellular context. J Biol Chem. (2017) 292:5443-56. doi: 10.1074/jbc.M116.763854

48. Li W, Xu J, Kou X, Zhao R, Zhou W, Fang X. Single-molecule force spectroscopy study of interactions between angiotensin II type 1 receptor and different biased ligands in living cells. Anal Bioanal Chem. (2018) 410:3275-84. doi: 10.1007/s00216-018-0956-3

49. Wingler LM, Elgeti M, Hilger D, Latorraca NR, Lerch MT, Staus DP, et al. Angiotensin analogs with divergent bias stabilize distinct receptor conformations. Cell. (2019) 176:468-478.e11. doi: 10.1016/j.cell.2018. 12.005

50. Takezako T, Unal H, Karnik SS, Node K. Current topics in angiotensin II type 1 receptor research: focus on inverse agonism, receptor dimerization and biased agonism. Pharmacol Res. (2017) 123:40-50. doi: 10.1016/j.phrs.2017.06.013

51. Ali MS, Sayeski PP, Dirksen LB, Hayzer DJ, Marrero MB, Bernstein KE. Dependence on the motif YIPP for the physical association of Jak2 kinase with the intracellular carboxyl tail of the angiotensin $\mathrm{II}_{\mathrm{AT}}{ }_{1}$ receptor. J Biol Chem. (1997) 272:23382-8. doi: 10.1074/jbc.272.37.23382

52. Daviet L, Lehtonen JY, Tamura K, Griese DP, Horiuchi M, Dzau VJ. Cloning and characterization of ATRAP, a novel protein that interacts with the angiotensin II type 1 receptor. J Biol Chem. (1999) 274:17058-62. doi: $10.1074 /$ jbc. 274.24 .17058

53. Marrero MB, Venema VJ, Ju H, Eaton DC, Venema RC. Regulation of angiotensin II-induced JAK2 tyrosine phosphorylation: roles of SHP-1 and SHP-2. Am J Physiol Physiol. (1998) 275:C1216-23. doi: 10.1152/ajpcell.1998.275.5.C1216

54. Venema RC, Ju H, Venema VJ, Schieffer B, Harp JB, Ling BN, et al. Angiotensin II-induced association of phospholipase $\mathrm{C} \gamma 1$ with the G-protein-coupled AT1 receptor. J Biol Chem. (1998) 273:7703-8. doi: $10.1074 /$ jbc.273.13.7703

55. Kendall RT, Luttrell LM. Diversity in arrestin function. Cell Mol Life Sci. (2009) 66:2953-73. doi: 10.1007/s00018-009-0088-1

56. Gurevich VV, Gurevich EV. GPCR signaling regulation: the role of GRKs and arrestins. Front Pharmacol. (2019) 10:125. doi: 10.3389/fphar.2019. 00125

57. Luttrell LM, Ferguson SS, Daaka Y, Miller WE, Maudsley S, Della Rocca GJ, et al. -arrestin-dependent formation of $\beta 2$ adrenergic receptor-Src protein kinase complexes. Science. (1999) 283:655-61. doi: 10.1126/science.283.5402.655

58. Luttrell LM, Roudabush FL, Choy EW, Miller WE, Field ME, Pierce KL, et al. Activation and targeting of extracellular signal-regulated kinases by $\beta$-arrestin scaffolds. Proc Natl Acad Sci USA. (2001) 98:2449-54. doi: $10.1073 /$ pnas. 041604898

59. McDonald PH, Chow CW, Miller WE, Laporte SA, Field ME, Lin FT, et al. -arrestin 2: a receptor-regulated MAPK scaffold for the activation of JNK3. Science. (2000) 290:1574-7. doi: 10.1126/science.290.5496.1574

60. Balakumar P, Jagadeesh G. Structural determinants for binding, activation, and functional selectivity of the angiotensin AT1 receptor. J Mol Endocrinol. (2014) 53:R71-92. doi: 10.1530/JME-14-0125 
61. Strungs EG, Luttrell LM. Arrestin-dependent activation of ERK and Src family kinases. Handb Exp Pharmacol. (2014). 219:225-57. doi: 10.1007/978-3-642-41199-1_12

62. DeWire SM, Kim J, Whalen EJ, Ahn S, Chen M, Lefkowitz RJ. $\beta$ Arrestin-mediated signaling regulates protein synthesis. J Biol Chem. (2008) 283:10611-20. doi: 10.1074/jbc.M710515200

63. Lymperopoulos A, Rengo G, Zincarelli C, Kim J, Soltys S, Koch WJ. An adrenal -arrestin 1-mediated signaling pathway underlies angiotensin IIinduced aldosterone production in vitro and in vivo. Proc Natl Acad Sci USA. (2009) 106:5825-30. doi: 10.1073/pnas.0811706106

64. Kendall RT, Strungs EG, Rachidi SM, Lee M-H, El-Shewy HM, Luttrell DK, et al. The $\beta$-arrestin pathway-selective Type $1 \mathrm{~A}$ angiotensin receptor (AT1A) agonist [Sar1,Ile4,Ile8]angiotensin II regulates a robust G protein-independent signaling network. J Biol Chem. (2011) 286:19880. doi: $10.1074 /$ jbc.M111.233080

65. Xiao K, Sun J, Kim J, Rajagopal S, Zhai B, Villén J, et al. Global phosphorylation analysis of $\beta$-arrestin-mediated signaling downstream of a seven transmembrane receptor (7TMR). Proc Natl Acad Sci USA. (2010) 107:15299-304. doi: 10.1073/pnas.1008461107

66. Shukla AK, Kim J, Ahn S, Xiao K, Shenoy SK, Liedtke W, et al. Arresting a transient receptor potential (TRP) channel. J Biol Chem. (2010) 285:3011525. doi: $10.1074 / j b c . M 110.141549$

67. Liu C-H, Gong Z, Liang Z-L, Liu Z-X, Yang F, Sun Y-J, et al. Arrestin-biased AT1R agonism induces acute catecholamine secretion through TRPC3 coupling. Nat Commun. (2017) 8:14335. doi: 10.1038/ncomms14335

68. Hermosilla T, Encina M, Morales D, Moreno C, Conejeros C, Alfaro-Valdés HM, et al. Prolonged AT1R activation induces CaV1.2 channel internalization in rat cardiomyocytes. Sci Rep. (2017) 7:10131. doi: 10.1038/s41598-017-10474-z

69. Ferrario CM, Mullick AE. Renin angiotensin aldosterone inhibition in the treatment of cardiovascular disease. Pharmacol Res. (2017) 125:57-71. doi: 10.1016/j.phrs.2017.05.020

70. Sayer G, Bhat G. The renin-angiotensin-aldosterone system and heart failure. Cardiol Clin. (2014) 32:21-32. doi: 10.1016/j.ccl.2013. 09.002

71. Zhai P, Yamamoto M, Galeotti J, Liu J, Masurekar M, Thaisz J, et al. Cardiacspecific overexpression of AT1 receptor mutant lacking Gq/Gi coupling causes hypertrophy and bradycardia in transgenic mice. JClin Invest. (2005) 115:3045-56. doi: 10.1172/JCI25330

72. Ohtsu H, Higuchi S, Shirai H, Eguchi K, Suzuki H, Hinoki A, et al. Central role of $\mathrm{G}_{\mathrm{q}}$ in the hypertrophic signal transduction of angiotensin II in vascular smooth muscle cells. Endocrinology. (2008) 149:3569-75. doi: 10.1210/en.2007-1694

73. Barnes WG, Reiter E, Violin JD, Ren X-R, Milligan G, Lefkowitz RJ. $\beta$-arrestin 1 and $G_{\alpha q / 11}$ coordinately activate RhoA and stress fiber formation following receptor stimulation. J Biol Chem. (2005) 280:8041-50. doi: $10.1074 /$ jbc.M412924200

74. Seta K, Sadoshima J. Phosphorylation of tyrosine 319 of the angiotensin II type 1 receptor mediates angiotensin II-induced trans-activation of the epidermal growth factor receptor. J Biol Chem. (2003) 278:9019-26. doi: 10.1074/jbc.M208017200

75. Smith NJ, Chan H-W, Qian H, Bourne AM, Hannan KM, Warner FJ, et al. Determination of the exact molecular requirements for type 1 angiotensin receptor epidermal growth factor receptor transactivation and cardiomyocyte hypertrophy. Hypertension. (2011) 57:973-80. doi: 10.1161/HYPERTENSIONAHA.110. 166710

76. Aplin M, Christensen GL, Schneider M, Heydorn A, Gammeltoft S, Kjølbye AL, et al. Differential extracellular signal-regulated kinases 1 and 2 activation by the angiotensin type 1 receptor supports distinct phenotypes of cardiac myocytes. Basic Clin Pharmacol Toxicol. (2007) 100:296-301. doi: 10.1111/j.1742-7843.2007.00064.x

77. Aplin M, Christensen GL, Schneider M, Heydorn A, Gammeltoft $\mathrm{S}$, Kjølbye $\mathrm{AL}$, et al. The angiotensin type 1 receptor activates extracellular signal-regulated kinases 1 and 2 by G protein-dependent and -independent pathways in cardiac myocytes and langendorffperfused hearts. Basic Clin Pharmacol Toxicol. (2007) 100:289-95. doi: 10.1111/j.1742-7843.2007.00063.x
78. Hunyady L, Turu G. The role of the AT1 angiotensin receptor in cardiac hypertrophy: angiotensin II receptor or stretch sensor? Trends Endocrinol. Metab. (2004) 15:405-8. doi: 10.1016/j.tem.2004.09.003

79. Yasuda N, Akazawa H, Qin Y, Zou Y, Komuro I. A novel mechanism of mechanical stress-induced angiotensin II type 1-receptor activation without the involvement of angiotensin II. Naunyn Schmiedebergs Arch Pharmacol. (2008) 377:393-9. doi: 10.1007/s00210-007-0215-1

80. Zou Y, Akazawa H, Qin Y, Sano M, Takano H, Minamino T, et al. Mechanical stress activates angiotensin II type 1 receptor without the involvement of angiotensin II. Nat Cell Biol. (2004) 6:499-506. doi: 10.1038/ncb1137

81. Lin L, Tang C, Xu J, Ye Y, Weng L, Wei W, et al. Mechanical stress triggers cardiomyocyte autophagy through angiotensin II type 1 receptormediated p38MAP kinase independently of angiotensin II. PLoS ONE. (2014) 9:e89629. doi: 10.1371/journal.pone.0089629

82. Naka T, Sakoda $\mathrm{T}$, Doi $\mathrm{T}$, Akagami $\mathrm{T}$, Tsujino $\mathrm{T}$, Masuyama $\mathrm{T}$, et al. Mechanical stretch induced interleukin-18 (IL-18) expression through Angiotensin subtype 1 receptor (AT1R) and endothelin1 in cardiomyocytes. Prep Biochem Biotechnol. (2008) 38:201-12. doi: 10.1080/10826060701885704

83. Oh Y-B, Gao S, Shah A, Kim JH, Park WH, Kim SH. Endogenous angiotensin II suppresses stretch-induced ANP secretion via AT1 receptor pathway. Peptides. (2011) 32:374-81. doi: 10.1016/j.peptides.2010.10.031

84. Saygili E, Rana OR, Meyer C, Gemein C, Andrzejewski MG, Ludwig A, et al. The angiotensin-calcineurin-NFAT pathway mediates stretch-induced upregulation of matrix metalloproteinases-2/-9 in atrial myocytes. Basic Res Cardiol. (2009) 104:435-8. doi: 10.1007/s00395-008-0772-6

85. Wang X, Petrie TG, Liu Y, Liu J, Fujioka H, Zhu X. Parkinson's disease-associated DJ-1 mutations impair mitochondrial dynamics and cause mitochondrial dysfunction. J Neurochem. (2012) 121:830-9. doi: 10.1111/j.1471-4159.2012.07734.x

86. Hong K, Zhao G, Hong Z, Sun Z, Yang Y, Clifford PS, et al. Mechanical activation of angiotensin II type 1 receptors causes actin remodelling and myogenic responsiveness in skeletal muscle arterioles. J Physiol. (2016) 594:7027-47. doi: 10.1113/JP272834

87. Hong K, Li M, Nourian Z, Meininger GA, Hill MA. Angiotensin II type 1 receptor mechanoactivation involves RGS5 (regulator of G protein signaling 5) in skeletal muscle arteries. Hypertension. (2017) 70:1264-72. doi: 10.1161/HYPERTENSIONAHA.117.09757

88. Mederos y Schnitzler M, Storch U, Meibers S, Nurwakagari P, Breit A, Essin $\mathrm{K}$, et al. Gq-coupled receptors as mechanosensors mediating myogenic vasoconstriction. EMBO J. (2008) 27:3092-103. doi: 10.1038/emboj.2008.233

89. Schleifenbaum J, Kassmann M, Szijártó IA, Hercule HC, Tano JY, Weinert S, et al. Stretch-activation of angiotensin II Type $1_{\text {a }}$ receptors contributes to the myogenic response of mouse mesenteric and renal arteries. Circ Res. (2014) 115:263-72. doi: 10.1161/CIRCRESAHA.115.302882

90. Miceli I, Burt D, Tarabra E, Camussi G, Perin PC, Gruden G. Stretch reduces nephrin expression via an angiotensin II-AT(1)-dependent mechanism in human podocytes: effect of rosiglitazone. Am J Physiol Renal Physiol. (2010) 298:F381-90. doi: 10.1152/ajprenal.90423.2008

91. Ramkhelawon B, Rivas D, Lehoux S. Shear stress activates extracellular signal-regulated kinase $1 / 2$ via the angiotensin II type 1 receptor. FASEB J. (2013) 27:3008-16. doi: 10.1096/fj.12-222299

92. Kippenberger S, Loitsch S, Guschel M, Müller J, Knies Y, Kaufmann $\mathrm{R}$, et al. Mechanical stretch stimulates protein kinase B/Akt phosphorylation in epidermal cells via angiotensin II type 1 receptor and epidermal growth factor receptor. J Biol Chem. (2005) 280:3060-7. doi: 10.1074/jbc.M409590200

93. Tang W, Strachan RT, Lefkowitz RJ, Rockman HA. Allosteric modulation of $\beta$-arrestin-biased angiotensin II type 1 receptor signaling by membrane stretch. J Biol Chem. (2014) 289:28271-83. doi: 10.1074/jbc.M114.585067

94. Malhotra R, D’Souza KM, Staron ML, Birukov KG, Bodi I, Akhter SA. G $\alpha_{\mathrm{q}}$ -mediated activation of GRK2 by mechanical stretch in cardiac myocytes. $J$ Biol Chem. (2010) 285:13748-60. doi: 10.1074/jbc.M110.109272

95. Rakesh K, Yoo B, Kim I-M, Salazar N, Kim K-S, Rockman HA. $\beta$-arrestinbiased agonism of the angiotensin receptor induced by mechanical stress. Sci Signal. (2010) 3:ra46. doi: 10.1126/scisignal.2000769

96. Wang S, Gong H, Jiang G, Ye Y, Wu J, You J, et al. Src is required for mechanical stretch-induced cardiomyocyte hypertrophy 
through angiotensin II type 1 receptor-dependent $\beta$-Arrestin2 pathways. PLoS ONE. (2014) 9:e92926. doi: 10.1371/journal.pone.0092926

97. Wang J, Hanada K, Gareri C, Rockman HA. Mechanoactivation of the angiotensin II type 1 receptor induces $\beta$-arrestin-biased signaling through $\mathrm{G} \alpha{ }_{i}$ coupling. J Cell Biochem. (2018) 119:3586-97. doi: 10.1002/jcb.26552

98. Boerrigter G, Soergel DG, Violin JD, Lark MW, Burnett JC. TRV120027, a novel $\beta$-arrestin biased ligand at the angiotensin II type I receptor, unloads the heart and maintains renal function when added to furosemide in experimental heart failure. Circ Hear Fail. (2012) 5:627-34. doi: 10.1161/CIRCHEARTFAILURE.112.969220

99. Tarigopula M, Davis RT, Mungai PT, Ryba DM, Wieczorek DF, Cowan CL, et al. Cardiac myosin light chain phosphorylation and inotropic effects of a biased ligand, TRV120023, in a dilated cardiomyopathy model. Cardiovasc Res. (2015) 107:226-34. doi: 10.1093/cvr/cvv162

100. Rajagopal K, Whalen EJ, Violin JD, Stiber JA, Rosenberg PB, Premont RT, et al. $\beta$-arrestin2-mediated inotropic effects of the angiotensin II type 1A receptor in isolated cardiac myocytes. Proc Natl Acad Sci USA. (2006) 103:16284-9. doi: 10.1073/pnas.0607583103

101. Abraham DM, Davis RT, Warren CM, Mao L, Wolska BM, Solaro RJ, et al. $\beta$-Arrestin mediates the Frank-Starling mechanism of cardiac contractility. Proc Natl Acad Sci USA. (2016) 113:14426-31. doi: 10.1073/pnas.1609308113

102. Kashihara T, Nakada T, Kojima K, Takeshita T, Yamada M. Angiotensin II activates $\mathrm{CaV} 1.2 \mathrm{Ca} 2+$ channels through $\beta$-arrestin2 and casein kinase 2 in mouse immature cardiomyocytes. J Physiol. (2017) 595:4207-25. doi: $10.1113 /$ JP273883

103. Soergel DG, Subach RA, Cowan CL, Violin JD, Lark MW. First clinical experience with TRV027: pharmacokinetics and pharmacodynamics in healthy volunteers. J Clin Pharmacol. (2013) 53:892-9. doi: 10.1002/ jcph.111

104. Pang PS, Butler J, Collins SP, Cotter G, Davison BA, Ezekowitz JA, et al. Biased ligand of the angiotensin II type 1 receptor in patients with acute heart failure: a randomized, double-blind, placebo-controlled, phase IIB, dose ranging trial (BLAST-AHF). Eur Heart J. (2017) 38:2364-73. doi: 10.1093/eurheartj/ehx196

105. Ryba DM, Li J, Cowan CL, Russell B, Wolska BM, Solaro RJ. Long-term biased $\beta$-arrestin signaling improves cardiac structure and function in dilated cardiomyopathy. Circulation. (2017) 135:1056-70. doi: 10.1161/CIRCULATIONAHA.116.024482

106. Tilley DG, Nguyen AD, Rockman HA. Troglitazone stimulates $\beta$ arrestin-dependent cardiomyocyte contractility via the angiotensin II type 1A receptor. Biochem Biophys Res Commun. (2010) 396:921-6. doi: 10.1016/j.bbrc.2010.05.023

107. AbdAlla S, Lother H, Quitterer U. AT1-receptor heterodimers show enhanced G-protein activation and altered receptor sequestration. Nature. (2000) 407:94-8. doi: 10.1038/35024095

108. Ayoub MA, Zhang Y, Kelly RS, See HB, Johnstone EKM, McCall EA, et al. Functional interaction between angiotensin II receptor type 1 and chemokine (C-C Motif) receptor 2 with implications for chronic kidney disease. PLoS ONE. (2015) 10:e0119803. doi: 10.1371/journal.pone. 0119803

109. Barki-Harrington L, Luttrell LM, Rockman HA. Dual inhibition of $\beta$ adrenergic and angiotensin II receptors by a single antagonist: a functional role for receptor-receptor interaction in vivo. Circulation. (2003) 108:1611-8. doi: 10.1161/01.CIR.0000092166.30360.78

110. Bellot M, Galandrin S, Boularan C, Matthies HJ, Despas F, Denis C, et al. Dual agonist occupancy of AT1-R- $\alpha 2 \mathrm{C}-\mathrm{AR}$ heterodimers results in atypical GsPKA signaling. Nat Chem Biol. (2015) 11:271-9. doi: 10.1038/nchembio.1766

111. Goupil E, Fillion D, Clément S, Luo X, Devost D, Sleno R, et al. Angiotensin II type I and prostaglandin F2 $\alpha$ receptors cooperatively modulate signaling in vascular smooth muscle cells. J Biol Chem. (2015) 290:3137-48. doi: 10.1074/jbc.M114.631119

112. Hansen JL, Theilade J, Haunsø S, Sheikh SP. Oligomerization of wild type and nonfunctional mutant angiotensin II type I receptors inhibits $\mathrm{G} \alpha \mathrm{q}$ protein signaling but not ERK activation. J Biol Chem. (2004) 279:24108-15. doi: 10.1074/jbc.M400092200
113. Jonas KC, Fanelli F, Huhtaniemi IT, Hanyaloglu AC. Single molecule analysis of functionally asymmetric G protein-coupled receptor (GPCR) oligomers reveals diverse spatial and structural assemblies. J Biol Chem. (2015) 290:3875-92. doi: 10.1074/jbc.M114.622498

114. Nishimura A, Sunggip C, Tozaki-Saitoh H, Shimauchi T, Numaga-Tomita T, Hirano K, et al. Purinergic $\mathrm{P} 2 \mathrm{Y}_{6}$ receptors heterodimerize with angiotensin AT1 receptors to promote angiotensin II-induced hypertension. Sci Signal. (2016) 9:ra7. doi: 10.1126/scisignal.aac9187

115. Siddiquee K, Hampton J, McAnally D, May L, Smith L. The apelin receptor inhibits the angiotensin II type 1 receptor via allosteric trans-inhibition. $\mathrm{Br} \mathrm{J}$ Pharmacol. (2013) 168:1104-17. doi: 10.1111/j.1476-5381.2012.02192.x

116. Szalai B, Barkai L, Turu G, Szidonya L, Várnai P, Hunyady L. Allosteric interactions within the AT1 angiotensin receptor homodimer: role of the conserved DRY motif. Biochem Pharmacol. (2012) 84:477-85. doi: 10.1016/j.bcp.2012.04.014

117. Zha D, Cheng H, Li W, Wu Y, Li X, Zhang L, et al. High glucose instigates tubulointerstitial injury by stimulating hetero-dimerization of adiponectin and angiotensin II receptors. Biochem Biophys Res Commun. (2017) 493:8406. doi: 10.1016/j.bbrc.2017.08.047

118. Wilson PC, Lee M-H, Appleton KM, El-Shewy HM, Morinelli TA, Peterson YK, et al. The arrestin-selective angiotensin AT1 receptor agonist [Sar1,Ile4,Ile8]-AngII negatively regulates bradykinin B2 receptor signaling via AT1-B2 receptor heterodimers. J Biol Chem. (2013) 288:18872-84. doi: 10.1074/jbc.M113.472381

119. Turu G, Szidonya L, Gáborik Z, Buday L, Spät A, Clark AJL, et al. Differential $\beta$-arrestin binding of AT1 and AT2 angiotensin receptors. FEBS Lett. (2006) 580:41-5. doi: 10.1016/j.febslet.2005.11.044

120. Carneiro de Morais CP, Polidoro JZ, Ralph DL, Pessoa TD, Oliveira-Souza M, Barauna VG, et al. Proximal tubule NHE3 activity is inhibited by $\beta$-arrestinbiased angiotensin II type 1 receptor signaling. Am J Physiol Physiol. (2015) 309:C541-50. doi: 10.1152/ajpcell.00072.2015

121. Feng Y-H, Sun Y, Douglas JG. G $\beta \gamma$-independent constitutive association of Gas with SHP-1 and angiotensin II receptor AT2 is essential in AT2mediated ITIM-independent activation of SHP-1. Proc Natl Acad Sci USA. (2002) 99:12049-54. doi: 10.1073/pnas.192404199

122. Lo Y-C, Rensi SE, Torng W, Altman RB. Machine learning in chemoinformatics and drug discovery. Drug Discov Today. (2018) 23:1538-46. doi: 10.1016/j.drudis.2018.05.010

123. Saulière A, Bellot M, Paris H, Denis C, Finana F, Hansen JT, et al. Deciphering biased-agonism complexity reveals a new active AT1 receptor entity. Nat Chem Biol. (2012) 8:622-30. doi: 10.1038/nchembio.961

124. Namkung Y, LeGouill C, Kumar S, Cao Y, Teixeira LB, Lukasheva V, et al. Functional selectivity profiling of the angiotensin II type 1 receptor using pathway-wide BRET signaling sensors. Sci Signal. (2018) 11:eaat1631. doi: 10.1126/scisignal.aat 1631

125. Grundmann M, Merten N, Malfacini D, Inoue A, Preis P, Simon K, et al. Lack of $\beta$-arrestin signaling in the absence of active $G$ proteins. Nat Commun. (2018) 9:341. doi: 10.1038/s41467-017-02661-3

126. Luttrell LM, Wang J, Plouffe B, Smith JS, Yamani L, Kaur S, et al. Manifold roles of $\beta$-arrestins in GPCR signaling elucidated with siRNA and CRISPR/Cas9. Sci Signal. (2018) 11:eaat7650. doi: 10.1126/scisignal.aat7650

127. Gurevich VV, Gurevich EV. Arrestin-mediated signaling: is there a controversy? World J Biol Chem. (2018) 9:25-35. doi: 10.4331/wjbc.v9.i3.25

Conflict of Interest Statement: The authors declare that the research was conducted in the absence of any commercial or financial relationships that could be construed as a potential conflict of interest.

Copyright (c) 2019 Turu, Balla and Hunyady. This is an open-access article distributed under the terms of the Creative Commons Attribution License (CC BY). The use, distribution or reproduction in other forums is permitted, provided the original author(s) and the copyright owner(s) are credited and that the original publication in this journal is cited, in accordance with accepted academic practice. No use, distribution or reproduction is permitted which does not comply with these terms. 